Esta revista forma parte del acervo de la Biblioteca Jurídica Virtual del Instituto de Investigaciones Jurídicas de la UNAM juhttp://www.juridicas.unam.mx/ https://biblio.juridicas.unam.mx/bjv DOI: http://dx.doi.org/10.22201/iij.24485306e.2021.2.15338

https://revistas.juridicas.unam. mx/ 


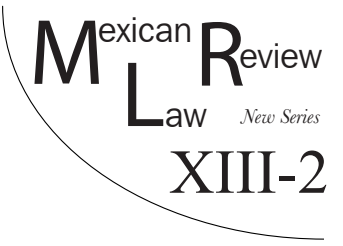

\title{
CORRUPTION, RULE OF LAW AND DEMOCRACY: CONGEPTS, BOUNDARIES AND OXYMORA
}

\author{
Stephen D. MORRIs*
}

\begin{abstract}
Despite heightened attention to corruption, multiple reform efforts, and democratization in the past few decades, corruption remains stubbornly persistent throughout the world. Much of the research on corruption highlights an inverse relationship linking corruption to the rule of law and to democracy. But rather than concentrate on the relationships among these critical variables, this research note focuses its attention on the intense debates in the literature over how to define these key concepts and the competing definitions. Analysis differentiates thin and thick definitions of each of the three concepts, highlights their shared emphasis on limiting state power and their use of vague criteria to demarcate the conceptual boundaries. Amid intense debate, all three essentially ground their limits on state power on rather vague notions of justice, equality, or the common or public good. The main argument here is that in many cases this results in a conceptual overlap and blurred boundaries. Depending on the definition employed, corruption can be seen as conceptually embedded within the notion of the rule of law which, in turn, is encompassed within our understanding of democracy. At one level, these common conceptual components potentially fashion tautologies and oxymora, complicating questions about the theoretical relationships among them: is it even possible for a country to have high levels of corruption and strong rule of law? Or high levels of corruption and yet still be considered democratic? At an empirical level, the conceptual overlap complicates the examination of such theoretical linkages because of endogeneity potential. I illustrate this problem briefly by noting how in some cases the indices of democracy encompass measures of the rule of law or corruption, and vice versa. The essay concludes
\end{abstract}

* Ph.D. from the University of Arizona. Researcher, Coordinación de Humanidades, Coordinador of the Laboratorio de la Documentación y Análisis de la Corrupción y Transparencia, Instituto de Investigaciones Sociales, UNAM and profesor of political science and international relations (on leave), Middle Tennessee State University. Contact: stephen.morris@humanidades.una m.mx and stephen.morris@mtsu.edu. Recent works include Corruption and Democracy in Latin America (co-edited with Charles Blake, 2009), and Corruption and Politics in Latin America: National and Regional Dynamics (co-edited with Charles Blake, 2010).

An earlier version of this note was presented at the XXXII International Congress of the Latin American Studies Association, May 21-24, 2014, Chicago, IL. 
Esta revista forma parte del acervo de la Biblioteca Jurídica Virtual del Instituto de Investigaciones Jurídicas de la UNAM

by highlighting how disaggregating the concepts raises other interesting questions and analytical challenges.

Keywords: Corruption, Rule of law, democracy, definitional debates, issues of endogeneity.

RESUMEN: A pesar de una mayor atención a la corrupción, esfuerzos varios en reformas, y una búsqueda por la democratización en las últimas décadas, la corrupción sigue aferrada por todo el mundo. Gran parte de las investigaciones realizadas sobre corrupción subrayan una relación inversa entre esta, el estado de derecho, y la democracia. En vez de concentrar la atención sobre las relaciones entre estas tres variables, la nota actual se enfoca en los debates contenciosos en la literatura sobre cómo definir estos conceptos claves, y las definiciones encontradas. El análisis destaca las distintas definiciones, tanto en sentido amplio como en estricto de cada uno de los tres conceptos, así como identificar el énfasis compartido sobre la limitación del poder del estado y su uso de criterio ambiguo para demarcar las fronteras conceptuales. Dentro de los debates, los tres conceptos esencialmente fundamentan los límites del poder estatal en ideas como justicia, igualdad, y el bien común o público. El argumento principal aqui es que en muchos casos esto resulta en la coincidencia conceptual produciendo fronteras borrosas. Según la definición estricta o amplia que se utilice, la corrupción se puede ver como incorporada dentro de la noción del estado de derecho, la cual, a su vez, está envuelta dentro del concepto de democracia. Los componentes compartidos pueden crear tautologías y oxímoros, complicando cuestiones teóricas entre los tres: ¿Es posible que un país sufra altos niveles de corrupción y también contar con un estado de derecho fuerte? $O$, ¿puede contar con altos niveles de corrupción, como corrupción electoral, y al mismo tiempo, ser una democracia? En adición, las coincidencias conceptuales complican cualquier investigación empirica sobre las relaciones entre la corrupción, estado de derecho y democracia por la posibilidad de endogamia. Ilustro este problema haciendo notar cómo en algunos casos los índices de la democracia incluyen mediciones del estado de derecho o corrupción. Desagregar estos conceptos también resalta otras inquietudes y retos analíticos.

Palabras claves: Corrupción, Estado de derecho, democracia, debates conceptuales, problemas de variables endógenas.

\section{TABLE of Contents}

I. INTRODUCTION.............................................................................. 155

II. Definitions, Goncepts and Overlap ........................................ 156

1. Corruption ..................................................................... 157

2. Rule of Law .................................................................... 161

3. Democracy ...................................................................... 164

III. Relationships Among Overlapping Concepts ......................... 167

IV. Conclusion: So? .............................................................. 170 
The British learned late in the eighteenth century that "influence" is nothing but a euphemism for "corruption", but contemporary political science chose to ignore this lesson. ${ }^{1}$

Adam PrZeworski

\section{INTRODUCTION}

Despite intense scholarly and political attention, multiple reforms, and theoretical and ideological expectations that corruption should wither as a result of expanding democratic and even neoliberal reforms,${ }^{2}$ corruption remains prevalent and stubbornly persistent throughout the world. In many countries today, despite empirical work showing correlations linking lower levels of corruption to both democracy and the rule of law, corruption and democracy seem to coincide. Weak rule of law and impunity seem to co-exist alongside "free and fair" elections, and the paucity of confidence in democratic institutions shadows the public's support for democracy as a system. Like many other countries, Mexico clearly fits this pattern.

At a fundamental level, these perplexing cocktails raise conceptual and theoretical questions, that possibly consists an oxymoron. Is it even possible for a country to be democratic and at the same time endure high levels of corruption or a weak rule of law? Could such a country strengthen its democracy while continuing to suffer high rates of corruption, impunity, and weak rule of law? If so, then how much (or what sorts of) corruption or un-rule of law is required to disqualify a country as being democratic? Could thresholds or criteria be established to differentiate acceptable from unacceptable levels of electoral fraud or the arbitrary use of power, or duplicitous exclusionary decision-making practices, or injustice, or impunity to deem a country as a non-democracy? Or do all three of these work alongside so that lowering corruption and strengthening the rule of law are part of becoming (more) democratic and vice versa? Essentially, are they different phenomena, or are they encased within one another located at higher and lower orders, or do they all refer fundamentally to the same things?

I pretend neither to answer all these questions here, explore the empirical or theoretical relationship linking these three variables, nor analyze them in relation to the Mexican case. Instead, the questions posed seek to underline the importance of conceptual clarity. After all, to even imagine a theoretical, causal relationship linking two or more variables, much less to test it empiri-

1 Adam Przeworski. Democracy and the limits of Self-government 97 (Cambridge University Press, 2010).

2 Anna Persson, Bo Rothstein, and Jan Teorell, Why Anticorruption Reforms Fail - Systemic Corruption as a Collective Action Problem, 26 (3) Governance: An International Journal of Policy Administration and Institutions 449-47 1 (2013). 
cally, it is necessary to rigorously define and measure the concepts in such a way that they are independent of one another. Yet as a conceptual exploration of competing thin and thick definitions and measures of corruption, rule of law, and democracy, it is somewhat difficult to see the three concepts as entirely separate and mutually exclusive, or as focusing on distinct phenomena. Conceptually, I argue, corruption is contained within most notions of the rule of law, just as the rule of law resides within most definitions of democracy. Broader or thicker definitions of both corruption and the rule of law further blur these conceptual boundaries by defining the terms along clearly democratic lines, just as thicker definitions of democracy encompass minimal levels of corruption, effective accountability, and rule of law. Much of this conceptual overlap stems from two common underlying components of these concepts: a shared concern for limiting state power, and the use of vague criteria rooted in notions of justice, equality, or the common good to demarcate those limits.

\section{Definitions, Goncepts and Overlap}

Despite intense debate and competing formulas, definitions of corruption, rule of law, and democracy, they share some important attributes as this review seeks to show. First, in one form or another, they all refer to limits on state power and/or the conduct of state officials. In Joseph Nye's classic and widelycited definition, for instance, corruption refers to behavior by a public official that deviates from the formal duties of a public office for personal gain. ${ }^{3}$ As such, corruption represents a breach of the normative limits placed on the conduct of state officials. In a similar manner, the rule of law also seeks to limit state power. At minimum, rule of law means that state officials must, like everyone else, abide by the law and respect certain limits on the arbitrary use of power. Democracy too is all about limiting the power of state officials. In the very least, democracy limits the mechanisms for selecting political leaders, and to some extent what governments can and cannot do. "Democracy's sweeping discretionary powers must operate through some set of decision rules and may not be used to violate core rights and periodic elections". "As Francis Fukuyama acknowledges, "Modern democracy was born when rulers acceded to formal rules limiting their power". ${ }^{5}$

The mere fact that all three concepts seek to limit state power creates a degree of conceptual overlap with each lower-level concept seemingly contained within the higher-level concept. Most notions of corruption are encompassed within our understanding of the rule of law, just as some basic

3 Joseph S. Nye, Corruption and Political Development: A Cost-Benefit Analysis, 61 American Poutitical Science Review 417-427 (1967).

4 Gerard Alexander, Institutionalized Uncertainty, the Rule of Lare, and the Sources of Democratic Stability, 35 Comparative Political Studies 1159 (2002).

5 Francis Fukuyama, The Necessity of Politics, in Essential Readings in Comparative PoliTics 33 (Patrick H. O’Neil and Ronald Rogowski eds., 2013). 
standards of the rule of law nestle within most definitions of democracy. In the simplest of terms this means that corrupt officials fail to abide by the rule of law, while countries that violate certain laws or rules - like those governing elections (i.e. staging them) - can hardly be considered democratic.

Beyond limiting state power, definitions of corruption, rule of law, and democracy also share two other ingredients. The first resides in the intense disagreement over how to define or specify those limits on state power or the conduct of state officials. In fact, specifying the norms that delimit the conduct of state officials, the law, or a democratic state, constitutes the rub of much of the conceptual debate featured in the abundant literature, and the key ingredient separating thin from thick definitions as described in detail below. Second, many definitions of corruption, rule of law, and democracy share a tendency to rely on fundamental principles of democracy, justice, equality, or the common good to define or demarcate these limits on state power. This shared dimension nurtures even greater conceptual overlap, and potential tautologies at the empirical level. Generally, the "thicker" the definition, the greater the overlap among the three concepts.

\section{Corruption}

The primary problem in defining corruption is to specify the standards that constitute the "norms" that an act of corruption violates. ${ }^{6}$ At one end of the spectrum, what can be called a thin definition of corruption tends to rely primarily on the law or the formal rules of public office to define, and identify an individual act as being corrupt. This is largely what Nye meant by the formal duties of public office. While using the law as the standard makes it easy to identify, gauge, and even quantify corruption, this approach has always raised questions. ${ }^{7}$ Not only can the law itself be the by-product of corruption and is usually determined by the politically powerful, but it also leaves open the matter of the criteria that should be used in making the law. ${ }^{8}$ Early on, analysts questioned the legal-based definition to suggest other criteria to define corrup-

6 An additional problem is the inclusion of private or personal gain in most definitions. As noted later, Dennis F. Thompson, Two Concepts of Corruption, Harvard University, Edmond J. Safra Center for Ethics, Working Papers, No. 16 (2013) distinguishes corruption involving private gain from corruption involving political gain. I argued many years back that from a rational choice perspective all acts are considered a function of personal gain, therefore, including it in a definition seems odd. Arguably all acts of public officials, corrupt and non-corrupt, are promoted by personal gain (Stephen D. Morris, Corruption and Politics in Contemporary Mexico 4 (University of Alabama Press, 1991).

7 Arnold J. Heidenheimer, ed., Political Corruption: Readings in Comparative Analysis (Transaction Books, 1970) and Mark Philp, Defining Political Corruption XLV Political STUdIES (1997).

8 L. L. Berg, H. Hahn and J. R. Schmidhauser, Corruption in the American Political System (General Learning Press, 1976). 
tion such as the common good or even public opinion, but these too quickly revealed their shortcomings. Of course, the use of any of these three earlier standards to demarcate corruption raises the question as to whether corruption can be legal, functional or popular.

More recent approaches in the study of corruption, however, broaden or "thicken" the definition in at least two important respects. ${ }^{9}$ First, these thick definitions define corruption not as a form of individual behavior, but as systemic. A reflection of how classical thinkers thought of corruption, this view envisions corruption as a form of rule that violates certain norms rather than considering it as individual acts. ${ }^{10}$ Michael Johnston, for example, characterizes corruption as a systemic problem having to do with the sources, uses, limits, and accountability of wealth and power: a form of influence that distorts decision-making, thereby diverting the costs and benefits of policy. ${ }^{11}$ Corruption defined in individualistic terms, Mark Warren contends, makes it difficult to conceive of "institutional corruption in which covert norms of exchange within an institution - access in exchange for campaign donations, for example - corrupt the overt purposes of the institution". ${ }^{12}$

But viewing corruption as systemic rather than individualistic still leaves unresolved the issue of how to define the norms or standards that constitute corruption. It is here where these new systemic approaches reach beyond the law (or public opinion or common good) to tap key principles of democracy denoting the standard or norm that corruption violates. Casting political inclusiveness as the key, for example, Warren conceptualizes corruption as the "duplicitous exclusion" of those affected by political decisions from exercising influence over those decisions. ${ }^{13}$ Corruption, he argues, "breaks the link be-

9 Ulrich Von Alemann, The Unknown Depths of Political Theory: The Case for a Multidimensional Concept of Corruption 42, Crime, Law \& Social Change (2004).

10 According to John Joseph Wallis, The Concept of Systematic Corruption in American History, in Corruption and Reform: Lessons from America's Economic History 25 (Edward L. Glaeser and Claudia Goldin, eds., 2006) this systemic view of corruption, wherein "politicians deliberately create rents by limiting entry into valuable economic activities, through grants of monopoly, restrictive corporate charters, tariffs, quotas, regulations, and the like... rents [which] bind the interests of the recipients to the politicians who create them", actually prevailed in the U.S. up to the Progressive Era. At that point, the individualist view became the accepted definition.

11 Michael Johnston (1997), Public Officials, Private Interests, and Sustainable Democracy: When Politics and Corruption Meet, in Corruption and the Global Economy (Kimberly Ann Elliott, ed. 1997); Michael Johnston, Democracy without Politics? The Hidden Costs of Corruption and Reform in America, in Corruption and American Politics 17 (Michael A. Genovese and Victoria A. Farrar-Myers, eds. 2010).

12 Mark E. Warren, What Does Corruption Mean in a Democracy? 48 (2) American Journal of Political Science, 331 (2004).

13 Ibid; Mark E. Warren, Political Corruption as Duplicitous Exclusion 39 (4) PS: Political ScIence and Politics (2006); and Mark E. Warren, Is Low Trust in Democratic Institutions a Problem of Corruption? in Corruption and American Politics (Michael A. Genovese and Victoria A. Farrar-Myers, eds., 2010). 
tween collective decision making and people's powers to influence collective decisions"; [and as a result] "reduces the effective domain of public action... by reducing public agencies of collective action to instruments of private benefit". ${ }^{14}$

Dennis Thompson, Lawrence Lessig, and Irma Sandoval-Ballesteros build further on Warren and Johnston's systemic approach. Thompson defines corruption as "a condition in which private interests distort public purposes by influencing the government in disregard of the democratic process". ${ }^{15}$ Shortly, whereas Warren points to the illegitimate exclusion of people from the decision making process, Thompson's systemic view seems to stress the illegitimate or privileged inclusion of others who bypass and hence undermine the democratic process to gain influence. Rather than duplicitous exclusion, the key democratic principle for Thompson, therefore, is whether the practice promotes political competition, citizen representation or other core processes of the democratic institution, or whether it undermines them, thereby weakening the independence of the institution. Lessig largely agrees with Thompson's formulation, but questions his notion of "institutional independence" by noting how the U.S. Congress is not expected to be independent, at least not from the will of the people. ${ }^{16}$ Consequently, Lessig coins the concept of "dependence corruption". In "dependence corruption" members of Congress are not only dependent on the moneyed interests that make their survival possible despite elections, but there is also no incentive by those benefiting from it to contest or reform the system. "The sin of a Congressman within such a system is not that she raises campaign money", Lessig notes. "It is that she doesn't work to change the corruption that this dependence upon a small set of funders has produced". ${ }^{17}$ But it is not merely that corruption undermines or affects principles of justice and legitimacy as the orthodox or thin view tends to suggest, ${ }^{18}$ but, the fact that corruption by definition constitutes a violation of the principles of justice and legitimacy.

Sandoval-Ballesteros's concept of "structural corruption" goes a step (or two) further. She defines corruption as a "specific form of social domination characterized by abuse, simulation, and misappropriation of resources arising from a pronounced differential in structural power". ${ }^{19}$ In broadening the

14 Warren, supra note 12.

15 Thompson, supra note 6.

16 Lawrence Lessig, Institutional Corruption, Edmond J. Safra Working Papers, No. 1, Harvard University, Edmond J. Safra Center for Ethics (March 15, 2013); Lawrence Lessig, Republic Lost: How Money Corrupts Congress - and a Plan to Stop It (Twelve, 2011 ).

17 Op. cit., 15.

18 Kurt Weyland, (1998) Politics of Corruption in Latin America, 9 (2) Journal of Democracy (1998).

19 Irma E. Sandoval-Ballesteros, From 'Institutional' to 'Structural' Corruption: Rethinking Accountability in a World of Public-Private Partnerships 9, Edmond J. Safra Working Papers, No. 33, Harvard University (2013). 
concept not just beyond the individual but beyond an institution, SandovalBallesteros sees this form of social domination as emerging not just from bureaucracy and politics, but also from semi-public organizations, the market, and the private sector all working together. Structural corruption, she contends, is a "highly sophisticated organized system that organically integrates economic, legal, social, administrative and political subsystems, linking lower and mid-level extortions, payoffs, bribes, etc. within a complete pyramidal structure of clientelism, institutionalized patronage, and impunity". 20 "What is ultimately in play within structural corruption is an environment of authoritarianism and social exclusion". ${ }^{21}$ Or as Przeworski notes, "The corruption of politics by money is a structural feature of democracy in economically unequal societies". 22

By drawing our attention to these systemic elements and the nature of decision making, these thicker definitions of corruption retrain our focus in two ways. First, they draw attention away from exclusively illegal behavior by individuals - a product of using the law as the standard determining corruption - to incorporate what some refer to as "legal" and institutional forms of corruption. ${ }^{23}$ Indeed, Thompson, Lessig and Johnston all focus on the legal forms of corruption occurring in the U.S., including campaign contributions and the buying of access and influence in Congress. ${ }^{24}$ Second, this new thicker, institutional/structural approach to corruption illuminates the political, decision-making arena rather than the administrative and implementation realm of politics most commonly associated with corruption. In contrasting these two arenas, Warren draws an important distinction between first and second order norms. First order norms, he notes, refer to the rules already crafted and set in law and policy. These prevail primarily within the administrative and executive realms. Second order norms, by contrast, guide and orient the process of deciding first order norms, and refer to more amorphous principles of openness, publicity, fairness, and inclusion that seek to control authoritative decision-making. ${ }^{25}$ These relate more to the deliberative

20 Ibid, 11.

21 Ibid, 12.

22 Przeworski 97, supra note 1. Aristotle, in The Social Contract, not only saw the unequal influence of groups over government as a form of corruption, but since this is rooted in societal inequalities, he considered this form of corruption investible (cited in Stephen Holmes, Linajes del Estado de Derecho, in Más Aldá del Acceso a la Información 70 [John M. Ackerman, ed., 2006]).

23 Charles Funderburk, Corruption in the United States: The Access Market, in Political CoRruption in Comparative Perspective: Sources, Status and Prospects. 19 (Funderburk ed., 2012). Thompson, supra note 6.

24 Thompson supra note 6; Lawrence Lessig, Institutional Corruption, Edmond J. Safra Working Papers, No. 1, Harvard University, Edmond J. Safra Center for Ethics (March 15, 2013); and Michael J. Johnston, Syndromes of Corruption: Wealth, Power, and Democracy (Cambridge University Press, 2005).

25 Warren, supra note 12. 
and discretionary side of politics. In many ways, this distinction builds on earlier distinctions in the literature between political versus administrative corruption. ${ }^{26}$

To be sure, those proposing these thicker, systemic views of corruption differentiate it conceptually from the more orthodox view of corruption rooted largely in individual behavior. Wallis, for instance, distinguishes systemic corruption from what he refers to as "venal corruption" defined as the pursuit of private economic interests through the political process. ${ }^{27}$ Warren similarly distinguishes the "corruption of public office" from "corruption of the democratic process". ${ }^{28}$ Thompson, in turn, differentiates between individual and institutional corruption based largely on the nature of the benefit and the service provided in return. ${ }^{29}$ While both forms of corruption effectively bypass the democratic process, institutional corruption involves political as opposed to personal gain, the service the official provides as systematic rather than episodic, and the connection between the benefit and the service as manifesting a tendency that disregards the democratic process. Such differentiation, of course, raises methodological challenges and theoretical questions regarding the relationship between these two classes of corruption: a point touched on later.

\section{Rule of Law}

Like writings on corruption, the literature on the rule of law also presents substantial debate over definition, providing readers with a host of competing meanings. ${ }^{30}$ What is formally referred to as the "thin" definition of the rule of law specifies minimal traits that the law must possess, but says nothing about the law's content. ${ }^{31}$ The "thin" definition, according to Flores and Himma, specifies that the law must be created by authorized bodies, be generalizable, and apply equally to all. 32 "Thicker" or substantive definitions of

26 Bardhan, The Economist's Approach to the Problem of Corruption 34 (2) WorLd Development (2006); James G. Scott, (1972) Comparative Political Corruption (Englewood Cliffs, Prentice-Hall, 1972).

27 Wallis, supra note 10.

28 Warren 46, supra note 13.

29 Thompson, supra note 6.

30 Brian Burge-Hendrix, Plato and the Rule of Law, in Law, Liberty and the Rule of Law (Flores and Himma, ed., 2013); Michael Zurn, Andre Nollkaemper, and Randall Peerenbook, eds. Rule of Law Dynamics in an Era of International and Transnational Governance (Cambridge University Press, 2012).

31 M. H. Kramer, Where Law and Morality Meet (Oxford University Press, 2004); J. Raz, The Authority of Law (Oxford, Clarendon, 1979).

32 Imer B. Flores and Kenneth Einar Himma, eds. Law, Liberty and the Rule of Law (Springer, 2013). For basic principles of the thin definition see Tom Bingham, The Rule of 
the rule of law lay on top of these requirements certain moral or political restrictions relating to the content of the law. These additional restrictions cover a wide range of areas from providing for and protecting basic liberties, private property, and human rights to the separation of powers and mechanisms of accountability and responsiveness. In a typical multi-layered definition encompassing both minimalist and substantive components, the UN Secretary-General's report on The Rule of Law and Transitional Fustice in Conflict and Post-Conflict Societies defines the rule of law as the "principle of governance in which all persons, institutions, and entities, public and private, including the State itself, are accountable to laws that are publicly promulgated, equally enforced, and independently adjudicated and which are consistent with international human rights norms and standards". 33

Clearly, both thin and thick definitions of the rule of law limit state power, but to different degrees. Minimalist or thin definitions restrict internally the conduct of officials by stating clearly that they too must abide by the law and not use power arbitrarily, and externally, claiming they must apply the law equally to all regardless of wealth or connections. Clearly, these components encompass the idea of corruption both in terms of state officials complying with the law, and in terms of favoring the interests of some over others. According to F.A. Hayek:

Stripped of all technicalities, [the 'Rule of Law'] means that government in all its actions is bound by rules fixed and announced beforehand - rules which make it possible to foresee with fair certainty how the authority will use its coercive powers in given circumstances and to plan one's individual affairs on the basis of this knowledge. ${ }^{34}$

Law (London: Allen Lane, 2010), L. L. Fuller, The Morality of Law 2nd edition (Yale University Press, 1969), and Raz, supra note 31. Bingham's widely accepted thin definition lays out eight defining principles: 1) the law must be accessible and so far as possible intelligible, clear and predictable; 2) questions of legal right and liability should ordinarily be resolved by application of the law and not the exercise of discretion; 3) laws should apply equally to all, save to the extent that objective differences justify differentiation; 4) ministers and public officers at all levels must exercise the powers conferred on them in good faith, fairly, for the purposes for which the powers were conferred, without exceeding the limits of such powers and reasonably; 5) the law must afford adequate protection of fundamental human rights; 6) means must be provided for resolving, without prohibitive cost or inordinate delay, bona fide civil disputes which the parties themselves are unable to resolve; 7) adjudicative procedures provided by the state must be fair; and 8) rule of law requires compliance by the state with its obligations in international as in national law.

33 Cited in Agnes Hurwitz and Kaysie Studdard, Rule of Law Programs in Peace Operations 2, Policy Paper of the International Peace Academy (August 2005).

34 F.A. Hayek, The Road to Serfdom 72 (University of Chicago Press, 1944) cited in Courtney Taylor Hamara, The Concept of the Rule of Law, in Law, LiberTy AND THE RULE OF LAW 18 (Imer B. Flores and Kenneth Einar Himma, eds, Springer, 2013). 
In short, the rule of law means that whatever the government does, it does based on law. ${ }^{35}$ Substantive or thicker definitions of the rule of law, in turn, limit state power even further by defining certain "moral" or political standards or restrictions that must be obeyed or respected by the state in the making and the implementation of the law. And just like thicker definitions of corruption that embrace legal forms of corruption, these broader formulas of the rule of law reach beyond the law itself to encompass basic principles of democracy and human rights. Guillermo O'Donnell, who distinguishes a minimal definition of the rule of law from what he appropriately calls the "democratic rule of law", for instance, stresses that the democratic rule of law "ensures political rights, civil liberties and mechanisms of accountability which in turn affirm the political equality of all citizens and constrain potential abuses of state power". ${ }^{36}$ Competing substantive definitions for the rule of law add a range of democratic features or limitations on state power. But despite such differences, according to Raz and O'Donnell, such moral restrictions center on the promotion of the common good and privileging the common over the personal good. ${ }^{37}$

$[\mathrm{T}]$ he rights of judges, of members of the legislature, and of all other legal officeholders are justified by the interests of the office... The ultimate justification of the rights depends on the fact that... they protect and promote the interest of the community as a whole; they promote and protect common goods. ${ }^{38}$

The overlap between corruption and rule of law at this point seems clear. Even a thin, legalistic definition of corruption captures behavior that represents a violation of the rule of law. But the overlap grows when employing thicker definitions of the two concepts. Regardless of the precise substantive components within a thick definition of the rule of law, by incorporating key principles of democracy and notions of the common good into the definition, it seem to parallel Warren's definition of corruption. ${ }^{39}$ Nonetheless, with "legal" corruption encompassed within a thick definition of corruption, these broader definitions of the rule of law suggest that officials may abide a particular law (i.e. act legally), yet fail to abide by the rule of law by way of violating underlying moral or democratic principles. Therefore, rule of law can be seen as extending beyond mere application of the law and formal rules for state

35 Brian Z. Tamanaha, On the Rule of Law: History, Politics, Theory 92 (Cambridge University Press, 2004).

36 Guillermo A. O'Donnell, Why the Rule of Law Matters, 15 (4) Journal of Democracy 32,33 (2004).

37 Raz 38, supra note 31.

38 Guillermo A. O’Donnell, Democracy, Agency and the State: Theory with ComParative Intent 99 (Oxford University Press, 2010).

39 Warren, supra notes 13 and 14. 
actors, to questions of how the law and decisions are made, how discretion is used, and how the law is interpreted and adjudicated. Certainly not all violations of the rule of law constitute corruption, but corruption seems clearly to represent a violation of the rule of law.

\section{Democracy}

Definitions of democracy fit this pattern as well. Years ago, Joseph Schumpeter set the standard for the thin definition by defining democracy in simple institutional and procedural terms as competitive elections. ${ }^{40}$ Many have embraced this minimal approach over the years. But noting how authoritarian regimes normally stage elections, critics contend that merely staging elections is not enough and that more is needed to make a regime truly democratic. The "more" that is required, however, varies but usually includes additional institutional guarantees, some role for the people, and, as definitions thicken, substantive outcomes. Those specifying additional institutional guarantees beyond elections, for instance, add such factors as civil liberties, ${ }^{41}$ freedom of expression and freedom of the press (alternative sources of information), ${ }^{42}$ contestation between legislature and the executive, ${ }^{43}$ horizontal mechanisms of accountability, ${ }^{44}$ the rule of law, ${ }^{45}$ alternation in power, ${ }^{46}$ and even anticorruption laws. ${ }^{47}$ Adding yet another layer (and hence further thickening the definition of democracy), some specify a role for the people, at least within elections, if not beyond. Beetham, for example, contends that the key to de-

40 Joseph Schumpeter, Capitalism, Socialism, and Democracy 251 (Harper Perennial, 1976).

41 Larry Diamond, Juan J. Linz and Seymour Martin Lipset, Politics in Developing Countries: Comparing Experiences with Democracy (Lynne Rienner, 1990); Freedom House. FreEdom IN THE WORLD 2010. Reports available at $h t t p: / /$ wererreffreedomhouse.org/reports\#. UyR16c7Hiro.

42 Robert A. Dahl, Polyarchy: Participation and Opposition (Yale University Press, 1971).

43 Mike Alvarez, Jose Antonio Cheibub, Fernando Limongi and Adam Przeworski, Classifying Political Regimes, 31 (2) Studies in Comparative International Development (1996).

44 Michael Coppedge, John Gerring, David Altman, Michael Bernhard, Steven Fish, Allen Hicken, Matthew Kroenig, Staffan I. Lindberg, Kelly McMann, Pamela Paxton, Holli A. Semetko, Svend-Erik Skaaning, Jeffrey Staton, and Jan Teorell, Conceptualizing and Measuring Democracy: A New Approach 9 (2) Perspectives on Politics (2011); Francis Fukuyama, Poverty, Inequality, and Democracy: Dealing with Inequality, 22 (3) Journal of Democracy (2011).

45 Fukuyama, supra note 44.

46 Alvarez et al., supra note 43.

47 Freedom House, supra note 41; Christian Welzel and Ronald Inglehart, Empancipative Values and Democracy: Response to Hadenius and Teorell, 41 (3) Studies in Comparative International Development (2006). See also Carles Boix, Michael Miller, and Sebastian Rosato, A Complete Data Set of Political Regimes, 1800-2007, 46 (12) Comparative Political Studies (2012). 
mocracy is not the matrix of rights, liberties and institutions, but "why particular institutions and rights are considered democratic". ${ }^{48}$ In addition, he proceeds to argue that the core idea of democracy is popular rule or control over decision making and political equality; hence institutions are democratic only if they contribute to popular control and political equality. ${ }^{49}$ Indeed, many analysts incorporate a high level of effective suffrage as part of the democratic criteria. ${ }^{50}$ Some go even further than participation to tack on specific substantive outcomes. These broader definitions of democracy reach beyond the political rights associated with elections to encompass social and economic rights and even different versions of equality. ${ }^{51}$ In characterizing the assorted substantive definitions of democracy, Alvarez et al. conclude that the scope of the different features associated with democracy is indeed broad: almost "all normative desirable aspects of political and sometimes even social and economic life are credited as definitional features of democracy". ${ }^{52}$

To begin with, even the thinnest of the thin definitions of democracy - procedural view stressing elections - points to a critical limit on state power: the means of selecting political leaders. Yet even minimalist definitions are not nearly as thin as they may appear. Despite definitions that seem to strive to concentrate solely on the procedural dimension of elections, most add a series of factors deemed necessary in order for elections to be considered truly democratic. ${ }^{53}$ As a general rule, elections must be "free and fair". This, however, is a rather difficult standard to apply and far more complicated than it may first appear. This requirement alone points to certain minimal standards and outcomes regarding the organization of elections, the fairness of the campaigns, the nature of the opposition, the role of the state (and incumbents) in the process, the counting and the reporting of the results, etc. ${ }^{54}$

Of course, such components of democracy, in turn, represent further limits on the use of state power (and the site of substantial abuse or corruption).

48 David Beetham, Democracy and Human Rights 90 (Polity Press, 1999) cited in Carl Henrik Knutsen, Measuring Effective Democracy, 31 (2) International Political Science Review $110(2010)$.

49 Ibid.

50 For example, Kenneth A. Bollen, Issues in the Comparative Measurement of Political Democracy, 44 American Sociological Review (1980); Michael Coppedge and Wolfgang H. Reinicke, Measuring Polyarchy, 25 Studies in Comparative International Development (1990); Dahl, supra note 42; Gerardo L. Munck, and Jay Verkuilen, Conceptualizing and Measuring Democracy, 35 Comparative Political Studies (2002).

51 Coppedge et al., supra note 44; Anthony Giddens, The Third Way: The Renewal of Social Democracy (Polity Press, 1998).

52 Alvarez et al. 4, supra note 43.

53 Stephen Holmes, Constitutionalism, in The Encyclopedia of Democracy Vol. 1 (Seymour M. Lipset, ed., Congressional Quarterly Press, 1995); Alexander, supra note 4.

54 Guillermo A. O’Donnell, Democracy, Law, and Comparative Politics, 36 (1) Studies in Comparative International Development 13 (2001). 
Boix et al., like Coppedge and Reinicke, who incorporate this factor into their definition of democracy, for example, define elections as fair: "if electoral fraud is absent and incumbents do not abuse government power to effectively eliminate the chance of opposition victory through peaceful contestation" (emphasis added). ${ }^{55}$ Clearly, these practices defining democracy envelope certain forms of corruption.

In addition to free and fair, most analysts also specify that elections must also be "competitive", meaning that there must not only be a choice for voters, but there must also be a degree of uncertainty in the outcome: the real possibility that the incumbent will lose and cede power. ${ }^{56}$ Beyond these electoral requirements for democracy to exist, some minimalist definitions add other freedoms and rights considered critical to making elections "free, fair, and competitive". In his definition of democracy, for example, O’Donnell includes not just fair elections, but also a) positive, participatory rights of voting, and b) "a set of freedoms that surround and are necessary supports for the likelihood of such elections and their related participatory rights". ${ }^{57} \mathrm{He}$ maintains that this is still a minimalist definition because it does not encompass all individual rights. ${ }^{58}$

To summarize the conceptual discussion thus far, it appears that while corruption, the rule of law, and democracy focus on restricting the power of the state and the conduct of state officials, there is substantial debate and disagreement over how to define those limits. For thinner approaches, the laws and the formal rules of the system seem to mark these boundaries. The state and its officials must abide by the law, conform to the formal duties of their office, respect the constitutional rights of citizens and behave in accordance to the law, conduct elections to select political leaders, as well as concede power to the victors. From this minimalist perspective, questions regarding corruption, the rule of law, and democracy seem to take on almost a legalistic tone: whether the state and state officials abide by the law, faithfully implement it, and abide the legal limits on how far the state can go in making laws.

55 Boix et al. 1531, supra note 47 like Coppedge and Reinicke, supra note 50.

56 Adam Przeworski, Democracy and the Market (Cambridge University Press, 1991). In his 2010 essay on the limits of self-government, Przeworski 46 (supra note 2) shows how incumbents rarely lose. This is due, in large part, to how the government institutionally never truly provides a level playing field to opponents.

57 O'Donnell 23, supra note 38.

58 Holmes (supra note 53), however, contends that by specifying certain rights and freedoms even so-called minimalist definitions are substantive. The requirement that these rights must exist not only defines elections, he notes, but also places limits on what a democratically elected government can do. Despite Przeworski's (supra note 50) minimalist notion that democracy is merely procedural and "institutionalizes uncertainty" over policy outcomes, democratic governments are not entirely free to operate in any manner they wish. These restrictions thus reduce the range of issues and range of possible outcomes. 
Yet thicker definitions of corruption, rule of law, and democracy reach beyond the law into far murkier terrain with significant overlap among the three. Here, attention comes to center more on whether the state or state officials comply with fundamental principles of democracy, the common good or pursuit of justice. Rather than simply a legalistic reading or emphasizing the proper implementation of the law, these thicker approaches focus more on the political side of the equation, on second order norms, on the spirit rather than the letter of the law, and on the content and substance of democracy rather than its procedural dimension.

\section{ReLATIONSHIPS AMONG \\ Overlapping Concepts}

All this points to significant conceptual overlap, boundaries, and even potential tautologies and oxymora. Table 1 seeks to highlight some of this by exploring the interrelationship of thin and thick definitions of corruption to thin and thick definitions of the rule of law and democracy. The matrix helps raise and address certain questions, some of which were raised at the beginning of this note: Does political corruption undermine the rule of law? Given the conceptual overlap, this question just strikes me as somewhat tautological since political corruption is an example of the failure of state officials (and citizens) to comply with the rule of law. Similarly, does corruption weaken democracy? Again, depending on what definitions we employ, then the absence of corruption (or at least certain forms of corruption) in part defines democracy (and vice versa), rendering the question somewhat tautological. 


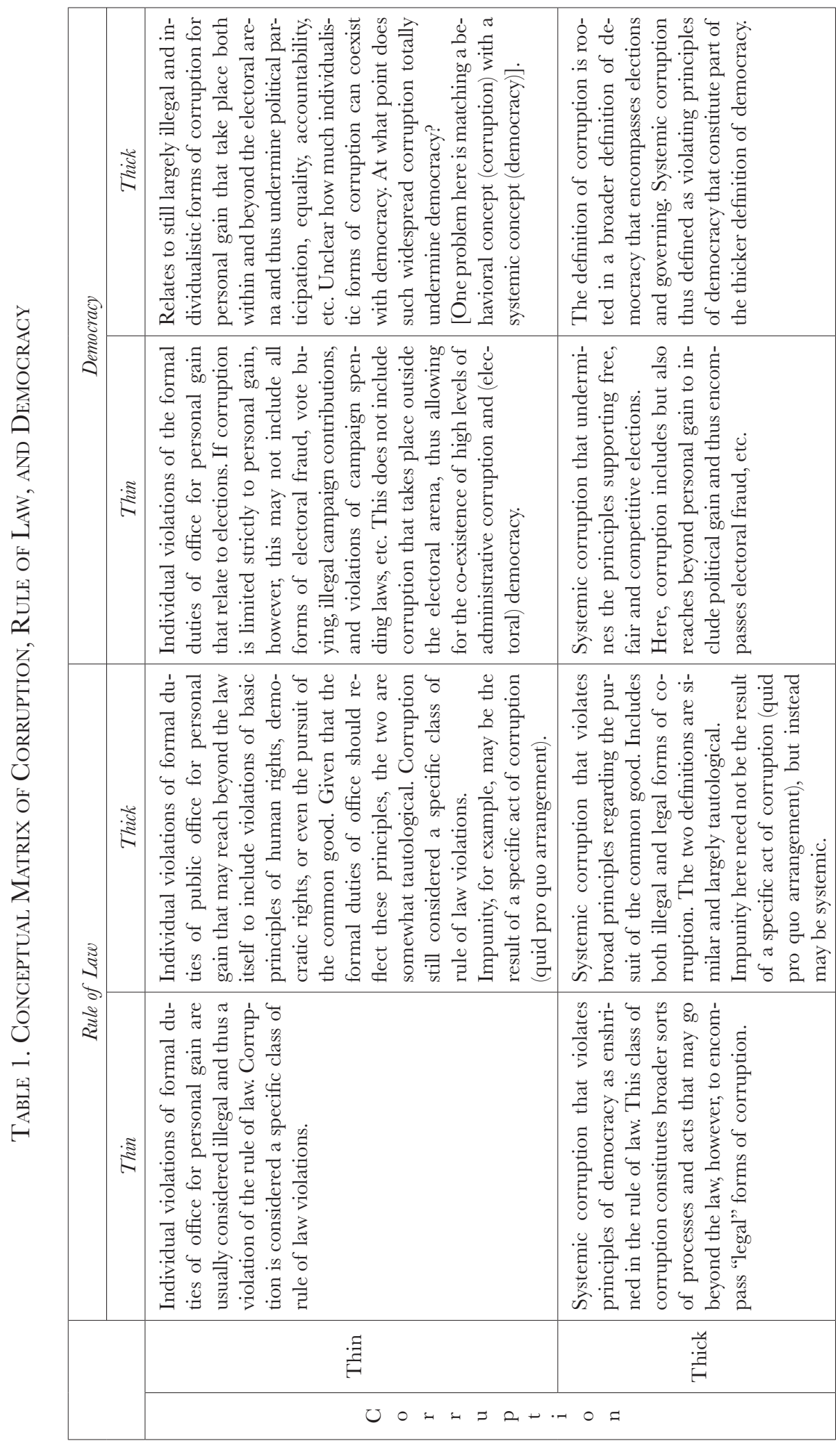


It terms of considering the relationships linking these concepts (and whether such theoretical questions even make sense), it becomes not only a question of conceptual clarity or recognizing the higher and lower order levels of the definitions (that corruption fits within rule of law which in turn fits within democracy). Instead, it centers on disaggregating the concepts and deciding how much of one is needed to determine the other. For instance, corruption represents a wide range of behavior and systemic arrangements. In a direct sense, corruption among police and the criminal courts undermines the state's enforcement of criminal law, while corruption within the courts and administrative levels undermines the implementation of civil and administrative law. If we employ thicker definitions of corruption and/or the rule of law, the degree of conceptual overlap expands. As noted, corruption in many of its forms (bribery, procurement corruption, conflict of interest, favoritism, graft, etc.) represents a failure of the government to either abide by the law and rules, or at least be held accountable. In this sense, corruption is certainly part of the violation of the rule of law - hence the conceptual overlap - but it is not the same thing. Nonetheless, corruption is not the only cause of the weak rule of law since deficiencies may reflect a wide range of factors from governmental structure (lack of judicial independence), political interference in the courts, and access to the legal system to the lack of resources and training among police and prosecutors. Corruption thus represents a lower level concept compared to rule of law.

Does political corruption undermine democracy? Most theories and studies, including my own, support this view. Noting the substantive relationship between democracy and the rule of law, the Inter-American Commission for Human Rights, for example, contends "that corruption constitutes a phenomenon that affects democratic institutions". ${ }^{59}$ But given the conceptual overlaps, such a question may be considered leaning at least toward tautology. Rather than affecting democracy, corruption represents, at least in part, the absence of democracy. Even using thin definitions of both corruption and democracy, certain types of corruption directly impact democracy and by definition undermine it. This includes, first and foremost, corruption related to electoral processes (electoral fraud, violation of campaign spending limits, etc.), and, secondly, the supporting political rights normally associated with free, fair and competitive elections. In other words, these forms of corruption undermine the fundamental qualities of democracy, disqualifying the regime as democratic: the two phenomena are not distinct. Within this narrow, thin perspective, of course, most traditional forms of bureaucratic corruption - bribery, extortion, conflicts of interest, etc. - arguably have little to no impact on elections and hence a thin minimalist definition of democracy. Here, the theoretical question makes sense: it is possible for democracy (defined as free and fair

59 Comisión Interamericana de Derechos Humanos, Corrupción y Derechos Humanos: Estándares Interamericanos 56 (Organización de Estados Americanos, 2019). 
elections) to co-exist with corruption (if by corruption you exclude corruption that undermines elections).

Moving beyond thin definitions the tautology and the connection between corruption and democracy become even greater. A broader definition of corruption means that corruption represents violations of the basic principles of democracy; similarly, a thick definition of democracy that includes accountability makes corruption a violation of the principles of democracy. As with the rule of law, corruption is not the only cause for the absence of democracy, but if the definition of democracy encompasses accountability, its presence would seem to disqualify a country as being democratic. This renders largely tautological the theoretical question of the relationship linking corruption to democracy.

Questions not shown in Table 1 can also be raised. Does weak rule of law undermine democracy? As with corruption, it largely depends on the specific types of rule of law problems. Weak rule of law related to campaigns and elections, which may undermine free, fair, and competitive elections, clearly distorts even a thin version of democracy. For thin definitions of democracy, however, weak rule of law in terms of criminal or civil enforcement, protection of private property, equal access to justice, equal treatment under the law, judicial independence, or obedience to the law really have no direct effect on democracy. As definitions thicken, of course, these concerns point to the weakness or lack of democracy and become increasingly tautological.

\section{Conclusion: So?}

Beyond the importance of conceptual clarity ${ }^{60}$ the current analysis raises questions regarding measures used to conduct empirical research and the results obtained. It also highlights how the multidimensional nature of the three concepts facilitate questions about the theoretical relationships among the various internal components of each. First, the overlap among the definitions of corruption, rule of law and democracy presents empirical challenges and the potential for endogeneity if used in an empirical model. Rather rudimentary measures of corruption are based on simple perceptions of corruption, while seemingly more sophisticated indices gauging the rule of law and democracy tend to incorporate among the range of indicators measures of corruption, its antithesis like accountability or, in the case of democracy, indicators of the rule of law, again highlighting the potential problem of endogeneity. Though a thorough review has been omitted for space purposes, a few examples serve to highlight the problem.

To begin with, many of the empirical measures of corruption center on perceptions, yet what those perceptions encompass remains unclear. Not only

60 Giovanni Sartori, Concept Misinformation in Comparative Politics, 64 American Political SciENCE REVIEW (1970). 
do we not know whether the subjective opinions reflect thin or thicker definitions of corruption, but it is also probable that perceptions of the rule of law and democracy are conflated within those perceptions of corruption. ${ }^{61}$ At the same time, the vast measures of the rule of law normally gauge whether state officials abide by the law and the norms governing their formal responsibilities: a clear reference to the essence of corruption. ${ }^{62}$ What has been said raises the question of whether a country could enjoy a high level of rule of law and yet widespread corruption, or the utility of a cross-national analysis regressing corruption along a measure of the rule of law. Indeed, one of the four components used to construct the World Justice Index (WJI) of the rule of law, for example, is whether government and its officials and agents are accountable under the law. Finally, measures of democracy frequently incorporate elements of both the rule of law and corruption. ${ }^{63}$ For instance, one of the 10 questions Freedom Houses uses in calculating its political rights index is whether the government is free from pervasive corruption, while another question asks about government accountability to the electorate between elections and whether it operates with openness and transparency. In fact, its political rights index even incorporates Transparency International's Corruption Perception Index. In a similar manner, the Polity IV scale of democracy includes among its components the existence of institutionalized constraints on the exercise of power by the executive: or, in short, a key component of anticorruption. ${ }^{64}$ Boix's et al. "complete data set of political regimes" stretching from 1800 to 2007 includes a measure of democracy that incorporates electoral fraud (a form of corruption), ${ }^{65}$ while Inglehart and Welzel's effective democracy index uses

61 Some contend that they reach beyond corruption to incorporate feelings about the government or even normative prejudices about the form of government. See John Bailey, Corruption and Democratic Governability in Latin America: Toward a Map of Types, Arenas, Perceptions, and Linkages, in Corruption and Democracy in Latin America (Charles H. Blake and Stephen D. Morris, eds., 2009). For discussion of the measures of corruption see Arturo Del Castillo, Medición de la CORRUPCión: un INDiCADOR DE LA RENDición de Cuentas (Mexico City: Auditoría Superior de la Nación 2003); Staffan Andersson, Beyond Unidimensional Measurement of Corruption, 19 (1) PuBLIC Integrity (2017); C. R. Apaza, Measuring Governance and Corruption through the Worldwide Governance Indicators: Critiques, Responses, and Ongoing Scholarly Discussion, 42 (1) PS: Political Science \& PoliTICs (2017); Tina Søreide, Is it Wrong to Rank? A Critical Assessment of Corruption Indices (Working 559 Paper, Chr. Michelsen Institute, 2006).

62 For reviews on existing measures of the rule of law see Wolfgang Merkel, Measuring the Quality of Rule of Law: Virtues, Perils, and Results, in Rule of Law Dynamics in an Era of International and Transnational Governance (Cambridge University Press, 2012) and Svend-Erik Skaaaning, Measuring the Rule of Law 63 (2) Political Research Quarterly (2010).

63 On measures of democracy see for instance Alex Inkles, ed. On Measuring Democracy (New Brunswick: Transaction, 1991); Kenneth A. Bollen, Liberal Democracy: Validity and Method Factors in Cross-National Measures, 37 (4) American Journal of Political Science (1993).

64 Polity IV Project: Political Regime Characteristics and Transitions, 1800-2012. Available at http://wrere.systemicpeace.org/polity/polity4.htm.

65 Boix's et al., supra note 47. 
either Transparency International's Corruption Perception Index (CPI) or the Control of Corruption index (CCI) from the World Governance Indicators (WGI). ${ }^{66}$ Interestingly - and tellingly from the perspective of this essay - the latter employs corruption as a proxy measure for the rule of law. ${ }^{67}$

Second, the current survey reveals the complexity and multidimensionality of corruption, the rule of law, and democracy - the many factors feeding competing definitions. This aggregation not only raises questions as to the validity of empirical measures as just noted, ${ }^{68}$ but also tends to obscure a deeper understanding of the rich internal attributes and questions about the theoretical relationships linking these internal components. What is the relationship, for instance, between corruption of public office (thin definition) and corruption of the democratic process (thick definition)? What is the relationship between legal and illegal forms of corruption, or high- and low-level forms of corruption, between corruption involving first order norms and second order norms? Does low-level, administrative corruption facilitate or inhibit higherlevel institutional or structural corruption? ${ }^{69}$ Is there an underlying tendency within societies away from illegal forms of corruption to more legal variants? Within the rule of law, under what conditions do the various aspects of the rule of law go together or collide? What factors and patterns shape impunity? Is there one legal system for the rich and another for the poor? Are certain rights more rigorously protected or certain laws better enforced than others? As for democracy, can free and fair elections coexist with the absence of accountability? To be sure, many have grappled with such issues. Exploring these issues at an empirical level, however, is complicated by the tendency to aggregate so many of these traits into singular metrics.

In pointing to the two common themes underlying corruption, rule of law, and democracy, the analysis helps us view corruption in a broader framework. The first relates to limits on the exercise of power by the state and state officials. In most cases, these limits are clearly defined by the laws, constitutional provisions and structures, and written rules and policies. Such first order norms define the normal duties of public offices, and the legal processes and procedures to make and implement authoritative decisions, to stage free,

66 Ronald Inglehart and Ghristian Welzel, Modernization, Gultural Ghange, and Democracy: The Human Development Sequence (Cambridge University Press, 2005) and Welzel and Inglehart, supra note 47.

67 Knutsen 116, supra note 48.

68 See Munck and Verkuilen, supra note 50.

69 Do they all represent a common underlying phenomenon? Johnston's (supra note 24) path-setting work provided a broad initial answer to this question, showing how patterns or syndromes of corruption in fact vary across countries: in other words that not all forms of corruption go together. The influence market corruption found in the US, for example, represents more the institutional and structural variants of corruption, while the elite cartel corruption found in Mexico includes more clearly illegal, administrative, and individualistic variants of corruption. Yet few have followed up on this approach. 
fair, competitive elections, etc. These norms are the historic by-product of societal interaction, power balances, negotiations, ideological struggles, compromises, crises and reforms, and conflicts that continue to play out. Consequently, clearly corrupt and blatantly anti-democratic acts are proscribed and illegal, making many, if not most, violations easy to spot, perceive, and count.

But just as the behavior of state officials, and citizens must conform to the law, those making decisions in the name of the state also face limits on how they arrive at their decisions and how they use their power and authority; i.e. second order norms. These limits, however, often go beyond the easily identifiable and quantifiable to encompass far more ambiguous and contested criteria rooted in the principles of democracy: the second common theme here. Corruption, as noted, goes beyond merely violating corruption statutes to include privileging the interest of some over others, the duplicitous exclusion of those affected by decisions from equal access to the decision makers, or when those making, implementing, or adjudicating the law take into account personal, partisan or other interests that do not center exclusively on the wellbeing of the people. Violating the rule of law similarly goes beyond merely breaking the law or even abiding by the "letter of the law" to incorporate criteria relating to the content of the law and the motives and reasons behind its creation, implementation or adjudication (thick or substantive definitions). In a similar manner, democracy is more than elections (thin definition), but fundamentally requires a government that is restricted in its use of power and bound by criteria involving the principles of inclusiveness, the privileging of the common good, accountability, responsiveness, and fundamental notions of justice (thick or substantive definitions).

For this reason, while aggregation pulls together multifaceted phenomenon to create the concepts of corruption, rule of law and democracy, these can be unpacked and explored. It is here where corruption broadly conceived becomes part of a larger concern over the perceived and real limits on (or abuse of) state power. This goes beyond questions about the patterns of corruption in a narrow sense to crystallize questions about the relationship between corruption and other abuses of state power or rule of law violations such as the abuse of human rights, the existence of informal rules in the decision-making process, clientelism, impunity, or the differential application of the law based on socioeconomic standing. Though this discussion has not encompassed society per se, corruption broadly conceived also raises questions cutting across state and society. For example, how does corruption or other broader violations of the rule of law or democracy by state officials influence society's ideas of legitimacy or of their obedience to the rule of law? Simply stated, does a high level of corruption (illegalities by officials) encourage citizens to break or bend the law whenever and wherever possible? In short, does state crime feed social crime? ${ }^{70}$ To broaden the matter a bit more, to what extent might corruption or

70 See, Stephen D. Morris, Mexico's Political Culture: The Unrule of Law and Corruption as a Form of Resistance, III (2) Mexican Law Review (2011). 
Esta revista forma parte del acervo de la Biblioteca Jurídica Virtual del Instituto de Investigaciones Jurídicas de la UNAM

other violations of the rule of law help hold democracy in check (by ensuring elite rule and preventing the people from making "certain" decisions) rather than the other way around? Under certain conditions, in a sort of Aristotelian balance, corruption and democracy may effectively co-exist with corruption taming democracy while democracy constrains corruption. 